\title{
HÌNH THẾ THỜI TIẾT GÂY MƯA LỚN TRONG THỜI KỲ MÙA ĐÔNG TRÊN KHU VỰC TÂY BẮC BỘ VIẸT NAM
}

\author{
Trần Đình Linh', Phạm Minh Tiến ${ }^{1}$, Chu Thị Thu Hường ${ }^{1}$
}

Tóm tắt: Nghiên cưu sủ dụng số liệu tái phân tích ERA Interim để xây dụng bản đồ trường đường dòng trên các mục đẳng áp chuẩn $1000 \mathrm{hPa}, 850 \mathrm{hPa}, 700 \mathrm{hPa}$ và $500 \mathrm{hPa}$ trong 134 ngày thuộc 35 đợt muxa lớn để xác định hình thế gây mua lớn trong thời kỳ mùa đông trên khu vục Tây Bắc Bộ. Kết quả cho thấy, ở các mưc duới của tầng đối lưu (1000hPa, 850hPa), hình thế thời tiết chủ yếu không thuận lợi để gây mura lớn. Phần lớn thời gian, ở các mưc này không khí lạnh chi phối ổn định trên khu vực. Ngược lại, hình thế ở các mục giũua đối lưu (700hPa, 500hPa) lại rất luận lợi để gây mua. Trong đa số các ngày xảy ra mưa lón, trên khu vực chịu ảnh hưởng rìa áp cao Thái Bình Dưong, rãnh gió tây hoặc sụ hội tu giữa chúng. Về vai trò gây mưa, hình thế ở các mưc giữa có vai trò quyết định trong phần lớn thời gian, trong đó, hình thế ở mục 700hPa có vai trò lớn hơn ở mưc 500hPa. Tuy vậy, trong một vài trương hợp khi hình thế ở các mưc giữa không thuận lợi, hình thế ở các mực dưới lại có vai trò quyết định.

Từ khóa: Hình thế thời tiết; Mura lớn thời kỳ mùa đông; Tây Bắc Bộ.

Ban Biên tập nhận bài: 12/7/2019 Ngày phản biện xong: 20/8/2019 Ngày đăng bài: 25/09/2019

\section{Mở đầu}

Việt Nam là đất nước nằm trong miền nhiệt đới gió mùa, thuộc vành đai nhiệt đới bán cầu Bắc. Vào thời kỳ mùa đông, Việt Nam chịu ảnh hưởng nhiều của không khí lạnh (KKL) với bản chất là khối không khí ngoại nhiệt đới có nguồn gốc từ áp cao lạnh lục địa Âu Á. Thời kỳ nửa đầu mùa, KKL thường biến tính qua lục địa tạo nên thời kỳ lạnh và khô hanh. Nửa sau mùa đông, KKL lại thường biến tính qua biển gây nên kiểu thời tiết lạnh ẩm, nhiều mây, có mưa nhỏ, mưa phùn và sương mù $[1,2]$. Trên khu vực Bắc Bộ, trong suốt thời kỳ gió mùa mùa đông, dù ảnh hưởng của $\mathrm{KKL}$ trải qua quá trình biến tính nào đi nữa thì vẫn là thời kỳ ít mưa với tổng lượng mưa trên khu vực trong thời gian này là không đáng kể [1].

Tuy nhiên, số liệu thực tế cho thấy ở Bắc Bộ cũng có những năm có lượng mưa gia tăng trong các tháng mùa đông, thậm chí lượng mưa tháng có thể vượt trên tiêu chuẩn mùa mưa $(100 \mathrm{~mm})$ với những đợt mưa lớn dị thường. Sự xuất hiện

${ }^{1}$ Trưòng Đại học Tài nguyên và Môi trưòng HN Email:tdlinh@hunre.edu.vn các đợt mưa lớn trong thơi kỳ này là rất hữu ích, nó cung cấp nguồn tài nguyên nước quí giá cho sản xuất và đời sống.

Về nguyên nhân gây mưa trong thời kỳ mùa đông ở Việt Nam, trước đây, phần lớn chúng ta cho rằng chủ yếu là do hoạt động của $\mathrm{KKL}$, trong đó front lạnh gần như là hệ thống nhiễu động gây mưa duy nhất ở Bắc Bộ trong thời kỳ này. Mặc dù vậy, kết quả nghiên cứu gầy đây cho thấy không phải tất cả các đợt xâm nhập lạnh xuống nước ta đều gây mưa và các đợt gây mưa thì đặc điểm mưa cũng khác nhau [3]. KKL tăng cường thường gây nên những đợt mưa tuy không lớn nhưng có thể xảy ra trên diện rộng ở các tỉnh thuộc khu vực Đông Bắc Bộ và ven biển Trung Bộ. Tuy vậy, cũng có những trường hợp KKL tăng cường làm giảm hoặc kết thúc mưa trên toàn lãnh thổ thuộc Bắc Bộ và Thanh Hóa [3]. Đối với các đợt gió mùa đông bắc, khi ảnh hưởng thường gây ra những đợt mưa trên diện rộng, đặc biệt là các tỉnh thuộc khu vực phía đông Bắc Bộ và ven biển Trung Bộ và lượng mưa thường lớn hơn khi có KKL tăng cường. Nhưng, cũng tương tự như khi KKL tăng cường, 
có những đợt gió mùa đông bắc gần như không gây mưa, mưa nếu có chỉ xảy ra ở vài nơi thuộc phía đông Bắc Bộ với lượng mưa không đáng kể [3].

Bên cạnh đó, áp cao lạnh lục địa là một hệ thống khí áp tầm thấp - trung, sự dịch chuyển của khối không khí từ trung tâm áp cao này phụ thuộc chủ yếu vào dòng gió trên cao phía sau trục rãnh Đông Á trong hệ thống dòng xiết gió tây cận nhiệt đới [4]. Cường độ và độ sâu của rãnh Đông Á ảnh hưởng đến sự dịch chuyển của áp cao Siberia làm KKL xâm nhập vào Việt Nam trực tiếp qua lục địa hay di chuyển lệch đông [4]. Hơn nữa, sự mạnh lên của dòng xiết Đông Á liên quan đến sự lạnh hơn và khô hơn ở khu vực Đông Á cũng như sự tăng cường đối lưu ở vùng xích đạo, nhiệt đới Á-Úc trong mùa đông [5]. Vị trí của trục dòng xiết cận nhiệt đới cũng có ảnh hưởng lớn trong việc tạo nên các ngày có lượng mưa trên $10 \mathrm{~mm}$ trên lưu vực sông Zayanderood, Iran [6]. Trong trường hợp tốc độ trong lõi dòng xiết cận nhiệt đới tương đương với tốc độ trong lõi của dòng xiết front cực thì cường độ mưa lớn hơn [6].

Bên cạnh ảnh hưởng của $\mathrm{KKL}$ và hoàn lưu trên cao đến sự thay đổi lượng mưa thì mối liên hệ gián tiếp giữa $\mathrm{ENSO}$ và nhiệt độ mặt nước biển (SST) với lượng mưa trên khu vực châu Á gió mùa nói chung cũng được các tác giả nghiên cứu $[7,8,9,10,11]$. Lượng mưa trên khu vực Bắc Bộ Việt Nam đều thâm hụt so với trung bình trong cả pha nóng và pha lạnh của ENSO [7]. Ở khu vực nam Trung Quốc, trong năm El-Nino hoặc năm có SST trên khu vực Biển Đông cao hơn trung bình thường xuất hiện dòng gió tây nam dị thường trên khu vực Biển Đông làm gia tăng dòng vận tải ẩm vào khu vực từ đó làm gia tăng lượng mưa trong các tháng $1,2,3$. Trong đó, ENSO ảnh hưởng chủ yếu đến mưa ở vùng phía nam, trong khi ảnh hưởng của SST là lớn hơn ở vùng phía bắc của khu vực nghiên cứu [8]. Cũng trên khu vực nam Trung Quốc, trong những mùa đông có lượng mưa gia tăng trên khu vực, hơi nước trong lớp khí quyển ở dưới mực $500 \mathrm{hPa}$ chủ yếu được vận chuyển bởi dòng gió Tây Nam và dòng gió Nam dị thường trên khu vực bán đảo Đông Dương và Biển Đông [9]. Lượng mưa mùa đông ở khu vực nam Trung Quốc biến đổi khoảng 20\%-30\% trong giai đoạn ENSO suy yếu, khoảng 20\% ở khu vực phía đông miền Trung Trung Quốc trong mùa xuân sau giai đoạn ENSO trung tính [10].

Đối với SST, ảnh hưởng của nó đến lượng mưa còn phụ thuộc lớn vào qui mô thời gian [11]. Trên khu vực Nhật Bản, với các qui mô thời gian từ vài ngày đến vài tuần, $\mathrm{SST}$ có ảnh hưởng rõ rệt đến lượng giáng thủy, trong khi, với qui mô thời gian từ 15 ngày đến tháng, ảnh hưởng là không rõ ràng [11]. Sự biến đổi lượng mưa trong các pha ENSO là do dị thường của hoàn lưu khí quyển trên khu vực trong thời kỳ tương ứng $[8,10]$.

Các kết quả nghiên cứu đã công bố cho thấy rằng, KKL có thể không phải là yếu tố chính, trực tiếp gây mưa ở Bắc Bộ trong thời kỳ mùa đông. Bên cạnh đó, quá trình xâm nhập vào Việt Nam của KKL cũng phụ thuộc vào hệ thống khác. Ngoài ra, sự gia tăng lượng mưa trên khu vực lân cận Việt Nam liên quan đến sự xuất hiện các dòng tải ẩm dị thường hay ảnh hưởng gây nên dị thường hoàn lưu trên khu vực của ENSO và $\mathrm{SST}$.

Trong bối cảnh đó, việc xác định hình thế thời tiết gây mưa lớn trên các mực khí áp cũng như vai trò của hình thế ở mỗi mực trong thời kỳ mùa đông ở Bắc Bộ có ý nghĩa khoa học và thực tiến cao. Trong nghiên cứu này, vấn đề trên bước được thực hiện cho khu vực Tây Bắc Bộ.

\section{Số liệu và phương pháp nghiên cứu}

\subsection{Giới thiệu khu vục nghiên cúu}

Nghiên cứu được thực hiện trên khu vực Tây Bắc Bộ. Phạm vi nghiên cứu gồm 04 tỉnh Lai Châu, Điện Biên, Sơn La và Hòa Bình thuộc quản lý của đài Khí tượng Thủy văn khu vực Tây Bắc (hình 1). 


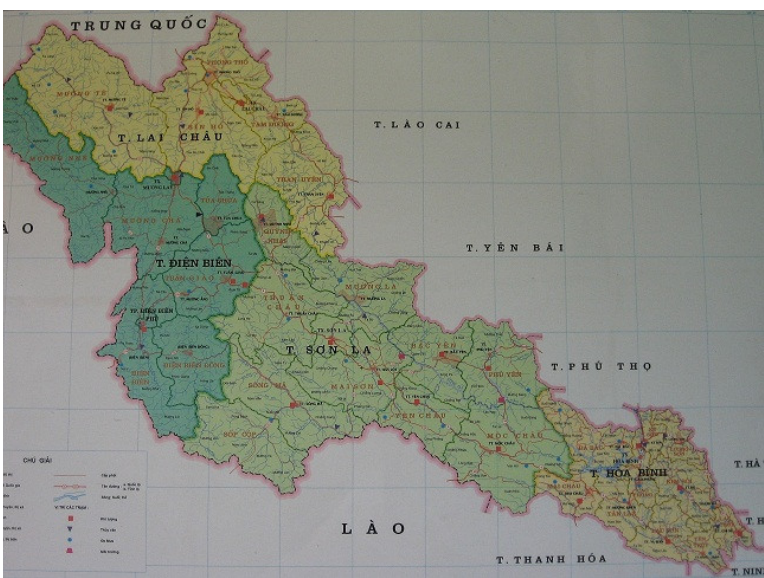

Hình 1. Khu vục nghiên cưu (nguồn: Website đài KTTV khu vục Tây Bắc)

\subsection{Số liệu}

Bài báo sử dụng hai nguồn số liệu để phục vụ nghiên cứu. Đó là số liệu quan trắc lượng mưa ngày của 13 trạm khí tượng trên khu vực Tây Bắc Bộ (bảng 1) và số liệu tái phân tích ERA-Interim của Trung tâm khí tượng hạn vừa châu Âu ECMWF. Thời gian khai thác của cả hai nguồn số liệu là 15 năm trong giai đoạn từ 2001 đến 2015. Trong đó, số liệu tái phân tích bao gồm các yếu tố: độ cao địa thế vị " $z$ ", tốc độ gió vĩ hướng "u” và tốc độ gió kinh hướng "v" tại các mực đẳng áp chuẩn từ mực $1000 \mathrm{hPa}$ đến $300 \mathrm{hPa}$. Nguồn số liệu này được lựa chọn với độ phân giải $0,5 \times 0,5$ độ kinh vĩ bao trùm khu vực từ 0 đến 50 độ vĩ Bắc, 60 đến 180 độ kinh Đông.

Bảng 1. Danh sách và vị trí của các trạm khí tượng phục vụ nghiên cứu

\begin{tabular}{cccccccc}
\hline \multirow{2}{*}{ TT } & \multirow{2}{*}{ Tên trạm } & \multicolumn{2}{c}{ Vị trí $^{*}$} & \multirow{2}{*}{ TT } & Tên trạm & \multicolumn{2}{c}{ Vị trí } \\
\cline { 3 - 4 } \cline { 7 - 8 } & & Vĩ độ & Kinh độ & Kinh độ \\
\hline 1 & Tam Đường & $22^{\circ} 25^{\prime}$ & $103^{\circ} 29^{\prime}$ & 8 & Sơn La & $21^{\circ} 20^{\prime}$ & $103^{\circ} 54^{\prime}$ \\
2 & Mường Tè & $22^{\circ} 22^{\prime}$ & $102^{\circ} 50^{\prime}$ & 9 & Phù Yên & $21^{\circ} 16^{\prime}$ & $104^{\circ} 38^{\prime}$ \\
3 & Sìn Hồ & $22^{\circ} 22^{\prime}$ & $103^{\circ} 14^{\prime}$ & 10 & Bắc Yên & $21^{\circ} 15^{\prime}$ & $104^{\circ} 25^{\prime}$ \\
4 & Than Uyên & $21^{\circ} 57^{\prime}$ & $103^{\circ} 53^{\prime}$ & 11 & Mộc Châu & $20^{\circ} 50^{\prime}$ & $104^{\circ} 41^{\prime}$ \\
5 & Điện Biên & $21^{\circ} 22^{\prime}$ & $103^{\circ} 00^{\prime}$ & 12 & Chi Nê & $20^{\circ} 29^{\prime}$ & $105^{\circ} 47^{\prime}$ \\
6 & Tuần Giáo & $22^{\circ} 35^{\prime}$ & $103^{\circ} 25^{\prime}$ & 13 & Lạc Sơn & $20^{\circ} 27^{\prime}$ & $105^{\circ} 27^{\prime}$ \\
7 & Pha Đin & $21^{\circ} 34^{\prime}$ & $103^{\circ} 31^{\prime}$ & & & & \\
\hline
\end{tabular}

\subsection{Phương pháp nghiên cứu}

\subsubsection{Lưa chon các đơt mura lón}

Do các hệ thống chi phối trên khu vực ở cả bề mặt và trên cao thường có sự thay đổi nội mùa nên khi xem xét xác định hình thế thời tiết trong các đợt mưa lớn, bài báo tiến hành lựa chọn các đợt mưa lớn giàn trải trong cả ba thời kỳ: đầu đông (tháng 11), giữa đông (tháng 12 , tháng 1 ) và cuối đông (tháng 2 , tháng 3 ). Theo đó, từ số liệu quan trắc lượng mưa ngày ở các trạm trên khu vực, bài báo cố gắng lựa chọn mỗi năm tối đa 03 đợt mưa lớn điển hình đại diện cho ba thời kỳ. Nếu một năm nào đó, trong một thời kỳ có nhiều hơn một đợn mưa lớn thì đợt mưa có diện và lượng mưa lớn hơn sẽ được lựa chọn. Mặc dù vậy, trong giai đoạn nghiên cứu có một số năm không có tới 03 đợt mưa lớn trải đều trong ba thời kỳ nên bài báo chỉ lựa chọn được tổng cộng 35 đợt, với 134 ngày mưa lớn trên khu vực. Trong số 35 đợt lựa chọn được, thời kỳ đầu đông có 11 đợt kéo dài trong tổng cộng 45 ngày, thời kỳ giữa đông có 10 đợt kéo dài trong 36 ngày và thời kỳ cuối đông có 14 đợt kéo dài trong 53 ngày.

2.2.2. Phưong pháp xác định hình thế thời tiết trong các đợt mura lón

Từ số liệu các đợt mưa lớn được lựa chọn, bài báo tiến hành xây dựng bộ bản đồ trường độ cao địa thế vị $(\mathrm{z})$ và đường dòng $(\mathrm{u}, \mathrm{v})$ từ số liệu tái phân tích trên các mực khí áp chuẩn $(1000 \mathrm{hPa}$, $850 \mathrm{hPa}, 700 \mathrm{hPa}$ và $500 \mathrm{hPa})$ trong tất cả các ngày của các đợt mưa lớn.

Từ bộ bản đồ xây dựng được, bài báo xác định hình thế trong từng ngày của từng đợt lần lượt cho các mực dưới tầng đối lưu $(1000 \mathrm{hPa}$ và $850 \mathrm{hPa})$ và các mực giữa tầng đối lưu $(700 \mathrm{hPa}$ và $500 \mathrm{hPa}$ ).

Kết quả xác định hình thế được thống kê chi tiết tương ứng theo từng hình thế, từng thời kỳ. Từ đó, xây dựng biểu đồ thể hiện đặc điểm hình 
thế cũng như sự thay đổi của nó theo thời gian ở các mực đẳng áp chuẩn.

2.2.3. Phuoong pháp xác định vai trò gây mưa lớn của hình thế trên các mưc

Để xem xét vai trò của hình thế ở các mực trong việc gây mưa lớn trong mùa đông trên khu vực, bài báo xem xét tổ hợp hình thế ở cả bốn mực khí áp trên trong tất cả các ngày có mưa lớn được lựa chọn phân tích. Đặc điểm hình thế ở một mực nào đó được kết luận có vai trò quan trọng hơn nếu hình thế ở mực đó thuận lợi để gây mưa lớn. Ngược lại, một mực nào đó có vai trò ít hơn nếu ở mực đó ít khi xuất hiện hình thế thuận lợi để gây mưa.

\section{Kết quả và thảo luận}

\section{đối luu \\ 3.1. Hình thế thời tiết ở các mục dưới tầng}

Ở mực $1000 \mathrm{hPa}$, kết quả phân tích cho thấy có 05 hình thế xuất hiện trong các ngày xảy ra mưa lớn trên khu vực Tây Bắc Bộ gồm KKL, KKL lệch đông (KKLLĐ), tương tác giữa KKL hoặc KKLLĐ với rìa áp thấp phía tây, tương tác giữa KKL với đới gió đông hoặc gió đông - đông nam và KKL tăng cường (KKLTC) (hình 2). Trong đó, phần lớn ở bề mặt bị khống chế bởi KKL (82/134 ngày) hoặc KKLLĐ (24/134 ngày), số ít còn lại là do sự chi phối của KKL hoặc KKLLĐ kết hợp với rìa áp thấp phía tây (22 ngày), tương tác giữa KKL với đới gió đông, đông nam (04 ngày) và KKL tăng cường (02 ngày).

Tần suất xuất hiện của các hình thế thay đổi theo thời gian từ đầu đông đến cuối đông, đồng thời sự thay đổi đó cũng khác nhau giữa các hình thế. Ví dụ như tần suất KKL chi phối trong các ngày mưa lớn giảm theo thời gian từ đầu đông đến cuối đông. Cụ thể, KKL xuất hiện nhiều hơn hai phần ba thời gian (33/45) trong thời kỳ đầu đông. Thời kỳ giữa đông, tỉ lệ này là gần hai phần ba (21/36) còn trong thời kỳ cuối đông nó giảm xuống chỉ còn gần một phần hai (26/53). Đối với KKLLĐ, tần suất xuất hiện nhiều hơn trong thời kỳ giữa đông còn đối với sự tương tác giữa KKL/KKLLĐ với áp thấp phía tây thì lại xuất hiện nhiều hơn trong thời kỳ cuối đông.

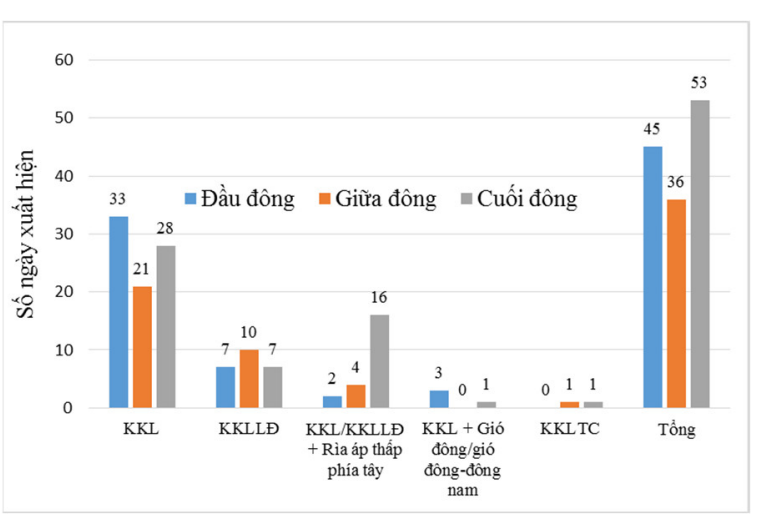

Hình 2. Hìn thế thời tiết mục 1000hPa và số ngày xuất hiện khi có mura lớn dị thuờng mùa đông trên khu vực Tây Bắc

Về hình thế ở mực $850 \mathrm{hPa}$, kết quả cho thấy có 08 hình thế (tổ hợp hình thế) chi phối trên khu vực trong những ngày khu vực xẩy ra mưa lớn. Theo tần suất xuất hiện từ lớn đến bé lần lượt là: KKL (HT1), Hội tụ giữa KKL và (hoặc) gió đông-đông nam và đới gió tây (HT2), KKL+Rìa ACTBD/ KKL+Rìa ACTBD+Rìa áp thấp phía tây/ KKL+Rìa ACTBD+Đới gió tây (HT3), KKL + Đới gió đông (HT4), KKLLĐ (HT5), KKL/KKLLĐ+Rìa áp thấp phía tây (HT6), KKL hoặc KKLLĐ + Gió tây nam từ rìa xoáy thuận dị thường trên vịnh Bengal (HT7) và KKLTC (HT8) (hình 3).

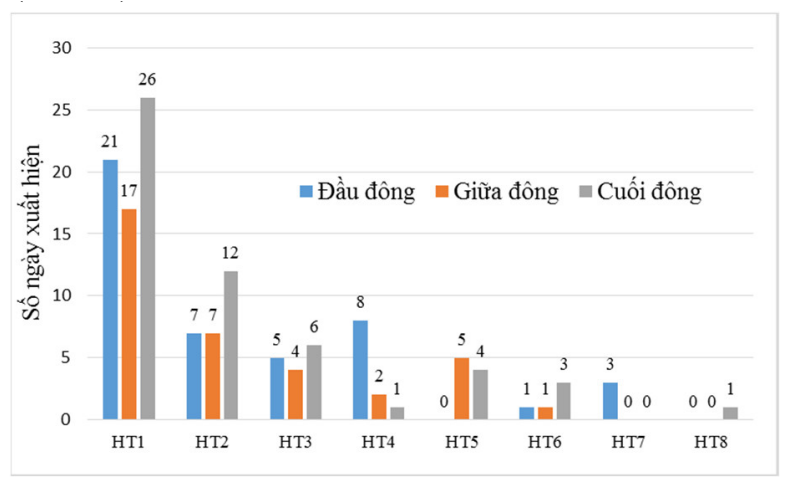

Hình 3. Tưong tụ hình 2 nhung ở mưc 850hPa

Như vậy, hình thế ở mực này khá tương đồng với hình thế ở mực $1000 \mathrm{hPa}$. Cụ thể, trong số 08 hình thế xuất hiện ở mực này, có 05 hình thế cũng xuất hiện mực $1000 \mathrm{hPa}$. Về tần suất xuất hiện, thống kê cho thấy KKL vẫn chi phối nhiều nhất (64/134 ngày). Tiếp theo, sự hội tụ giữa KKL và (hoặc) gió đông nam với đới gió tây có 
tần suất xuất hiện lớn thứ hai (26/134 ngày). Các hình thế gồm sự tương tác giữa $\mathrm{KKL}$ với đới gió đông, tương tác giữa $\mathrm{KKL}$ với rìa $\mathrm{ACTBD}$ và KKLLĐ có tần suất xuất hiện lần lượt lớn thứ ba, thứ tư và thứ năm $(11 / 134,10 / 134$ và $9 / 134$ ngày). Các hình thế như tương tác giữa $\mathrm{KKL}$ hoặc KKLLĐ với rìa áp thấp phía tây, tương tác giữa KKL hoặc KKLLĐ với gió tây tam từ rìa xoáy thuận dị thường trên vịnh Bengal và KKLTC có tần suất xuất hiện nhỏ.

\subsection{Hinh thế ở các mục giữa tầng đối lưu}

Kết quả phân tích, thống kê cho thấy trong cả mùa đông tổng cộng có 06 hình thế ở mực $700 \mathrm{hPa}$ và $5 / 6$ hình thế đó xuất hiện ở mực 500hPa xuất hiện khi trên khu vực xảy ra mưa lớn, gồm: Hội tụ giữa rìa áp cao Thái Bình Dương (ACTBD) với rãnh gió tây (HT9), Rìa ACTBD (HT10), Rãnh gió tây (HT11), Đới gió tây (HT12), Hội tụ giữa rìa $\mathrm{ACTBD}$ và gió tây nam từ rìa xoáy thuận dị thường trên vịnh Bengal (HT13) và ACTBD (HT14) (hình 4). Ở mực $700 \mathrm{hPa}$, ba hình thế gồm hội tụ giữa rìa $\mathrm{ACTBD}$ với rãnh gió tây, rìa $A C T B D$ và rãnh gió tây/xoáy thấp lần lượt có tần suất chi phối lớn nhất với số ngày chi phối lần lượt là 57 ngày, 37 ngày và 19 ngày trên tổng số 134 ngày được phân tích. Cả ba hình thế này đều rất thuận lợi cho sự xuất hiện mưa lớn trên bất kỳ khu vực nào mà nó chi phối. Với tổng số 113 xuất hiện trên tổng số 134 ngày cho thấy vai trò quan trọng của ba hệ thống này trong các đợt mưa lớn vào mùa đông trên khu vực.

Bên cạnh sự chi phối của các hình thế ở trên, kết quả ở hình 3 cũng cho thấy sự xuất hiện các hình thế không thuận lợi để gây mưa trên khu vực. Tuy nhiên, số ngày xuất hiện các hình thế này chỉ chiếm thiểu số. Tổng số có 17 ngày, trong đó 13 ngày khu vực chịu sự chi phối của đới gió tây và 04 ngày là sự chi phối của $\mathrm{ACTBD}$ là không thuận lợi cho sự xuất hiện mưa lớn.

Theo từng thời kỳ, tổng số hình thế và thời gian chi phối của mỗi hình thế cũng có sự thay đổi như ở các mực dưới thấp. Ba hình thế xuất hiện nhiều nhất được đề cập ở trên cùng với sự chi phối của đới gió tây phân tích được trong cả ba thời kỳ. Trong khi sự hội tụ giữa rìa $\mathrm{ACTBD}$ với gió tây nam từ rìa xoáy thuận dị thường trên vịnh Bengal chỉ xuất hiện 04 ngày trong thời kỳ giữa đông, bên cạnh đó sự chi phối của ACTBD thì không xuất hiện trong các ngày mưa lớn trong thời kỳ cuối đông. Về khả năng xuất hiện, trong thời kỳ đầu đông, rìa $\mathrm{ACTBD}$ chi phối nhiều nhất, còn trong hai thời kỳ sau, sự hội tụ giữa rìa $\mathrm{ACTBD}$ với rãnh gió tây có tần suất lớn nhất, đặc biệt trong thời kỳ cuối đông khi hình thế này chi phối gần nửa số ngày có mưa lớn. Kết quả này là phù hợp với đặc điểm hoạt động của $\mathrm{ACTBD}$ và dòng xiết gió tây cận nhiệt đới $[2,3]$.

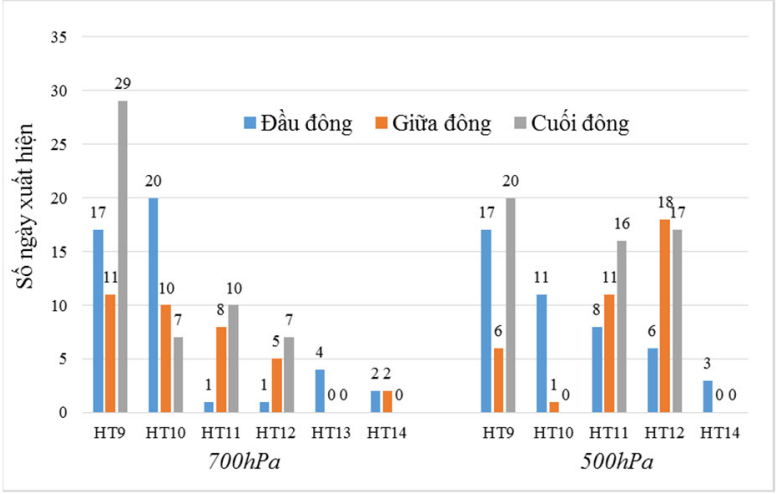

Hình 4. Tuong tụ hình 2 nhung ở mục 700hPa và mucc 500hPa

Ở mực $500 \mathrm{hPa}$, bốn hình thế có thời gian chi phối nhiều nhất lần lượt là hội tụ giữa rìa ACCNĐ với rãnh gió tây, đới gió tây, rãnh gió

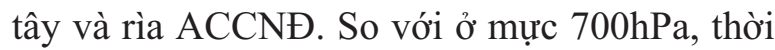
gian chi phối của hội tụ giữa rìa $\mathrm{ACCNĐ} \mathrm{với}$ rãnh gió tây và rìa $\mathrm{ACCNĐ} \mathrm{giảm} \mathrm{xuống} \mathrm{đáng} \mathrm{kể,}$ đặc biệt là sự suy giảm thời gian chi phối của rìa ACCNĐ. Ở mực này, tổng thời gian chi phối của rìa $\mathrm{ACCNĐ} \mathrm{chỉ} \mathrm{còn} 12$ ngày, chỉ bằng gần một phần ba so với mực $700 \mathrm{hPa}$, trong đó thời kỳ giữa đông chỉ còn 01 ngày, thậm chí, thời kỳ cuối đông hình thế này còn không xuất hiện trong các ngày xảy ra mưa lớn. Bù lại sự suy giảm của hai hình thế trên là sự gia tăng thời gian chi phối của rãnh gió tây cũng như đới gió tây. Trong đó, sự gia tăng thời gian chi phối của rãnh gió tây là lớn hơn.

Khi trên khu vực xuất hiện đới gió tây hoặc ACCNĐ chi phối thì nhìn chung không thuận lợi cho sự xuất hiện mưa. Tổng số ngày có sự chi 
phổi của hai hình thế này là khá lớn (44/134 ngày) cho thấy vai trò của hoàn lưu mực này có thể không lớn bằng đặc điểm hoàn lưu ở mực $700 \mathrm{hPa}$.

\subsection{Tổ hợp hình thế trên các mục gây mưa} lớn dị thường thời kỳ mùa đông trên khu vụcc

Chúng ta biết rằng, khi khu vực bị KKL chi phối ổn định ở tầng thấp nếu HTTT ở trên cao không thuận lợi thì thời tiết trên khu vực thường khô hanh [1]. Kết quả trên cho thấy KKL và KKLLĐ khống chế ở hai mực $1000 \mathrm{hPa}$ và $850 \mathrm{hPa}$ chiếm đa số các ngày xảy ra mưa lớn dễ gây mâu thuẫn. Tuy nhiên, khi tiến hành phân tích đồng thời tổ hợp hình thế các mực cho thấy trong những ngày xảy ra mưa lớn mà có KKL hoặc KKLLĐ chi phối ở mực 1000hPa hoặc cả hai mực trong tầng đối lưu dưới thì ở trên cao hình thế là rất thuận lợi để gây mưa. Trong cả ba thời kỳ, hầu hết các ngày ở tầng dưới có KKL chi phối ổn định, ở tầng giữa đối lưu xuất hiện sự hội trong đới gió tây hoặc hội tụ giữa rìa ACTBD với rãnh gió tây hay khu vực nằm ở rìa phía tây bắc của ACCNĐ ở cả hai mực hoặc ít nhất một trong hai mực 700hPa hoặc 500hPa (bảng 2, 3, 4).

Trong thời kỳ đầu đông (bảng 2), tất cả 21 ngày ở tầng đối lưu dưới có sự chi phối của KKL hoặc KKLLĐ thì ở các mực giữa tầng đối lưu hình thế đều thuận lợi để gây mưa. Với riêng mực $1000 \mathrm{hPa}$ có đến 40/45 ngày xuất hiện mưa lớn nhưng hình thế là không thuận lợi, điều này đồng nghĩa rằng hệ thống ở sát bề mặt ít có vai trò gây mưa lớn trong mùa đông trên khu vực. Ngược lại, tất cả 45 ngày được phân tích, ở tầng đối lưu giữa ít nhất tồn tại một mực có hình thế thuận lợi để gây mưa. Trong đó, mực $700 \mathrm{hPa}$ chỉ có 3/45 ngày, mực 500hPa có 9/45 ngày trên khu vực có hình thế không thuận lợi khi bị khống chế bởi ACTBD hoặc đới gió tây.

Thời kỳ giữa đông (bảng 3 ), trong 22/36 ngày xảy ra mưa lớn mà hình thế ở cả hai mực trong tầng đối lưu dưới không thuận lợi có đến 21 ngày hình thế ở các mực giữa của tầng đối lưu thuận lợi để gây mưa. Tổng cộng, 31/36 ngày ở tầng đối lưu giữa có hình thế thuận lợi trên ít nhất một trong hai mực được xét. Về hình thế không thuận lợi gây mưa ở các mực giữa tầng đối lưu trong thời kỳ này có xu hướng tăng lên so với thời kỳ trước khi mực $700 \mathrm{hPa}$ có 07 ngày còn mực $500 \mathrm{hPa}$ có đến 17 ngày, trong đó có 5 ngày đồng thời cả hai mực có hình thế không thuận lợi.

Trong tổng số 53 ngày được phân tích ở thời kỳ cuối đông, 26 ngày có hình thế không thuận lợi ở cả hai mực dưới của tầng đối lưu (bảng 4). Trong đó, 24/26 ngày có hình thế thuận lợi ở các mực giữa. Trong thời kỳ này, số ngày hình thế ở các mực giữa có hình thế không thuận lợi không thay đổi so với thời kỳ giữa đông. Tuy nhiên, tần suất xuất hiện giảm do số ngày được phân tích tăng lên. Kết quả trên cho thấy đặc điểm hoàn lưu ở các mực giữa tầng đối lưu có vai trò quan trọng hơn so với các mực dưới trong cả ba thời kỳ. Điều này rất có thể là nguyên nhân dẫn đến sự bất đồng nhất trong hệ quả thời tiết khi KKL ảnh hưởng như công bố của Phạm Vũ Anh và cs năm 2010 [3].

Trong hai mực $700 \mathrm{hPa}$ và $500 \mathrm{hPa}$, vai trò của hình thế mực $700 \mathrm{hPa}$ gần như có tính quyết định hơn khi tần suất xuất hiện các hình thế thuận lợi để gây mưa ở mực này cao hơn ở mực $500 \mathrm{hPa}$ trong suốt mùa đông, đặc biệt trong những ngày ở các mực dưới có hình thế không thuận lợi.

Tuy vai trò của hình thế ở các mực giữa quan trọng hơn nhưng chúng ta cũng không thể bỏ qua việc phân tích hình thế ở các mực dưới trong nghiên cứu cũng như dự báo mưa lớn thời kỳ mùa đông, đặc biệt trong những ngày có hình thế không thuận lợi ở các mực giữa tầng đối lưu. Kết quả phân tích trong 134 ngày được lựa chọn cho thấy, có 10 ngày hình thế ở các mực giữa đều không thuận lợi. Trong tất cả những ngày này, hình thế ở mực dưới đều thuận lợi để gây mưa và có vai trò quyết định. Bên cạnh đó, so với mực $1000 \mathrm{hPa}$, hình thế ở mực $850 \mathrm{hPa}$ thường thuận lợi để gây mưa hơn.

Ngoài ra, trong số 134 ngày mưa lớn được phân tích có 03 ngày ở cả bốn mực khí áp chuẩn trên khu vực đều có hình thế không thuận lợi. Sự xuất hiện mưa lớn trong những ngày này có thể là do KKL kèm theo front lạnh ở tầng thấp. Tuy nhiên, trong khuôn khổ bài báo này, vấn đề này 
chưa được làm rõ.

\section{Kết luận}

Qua phân tích đặc điểm hình thế thời tiết ở các mực đẳng áp chuẩn gồm $1000 \mathrm{hPa}, 850 \mathrm{hPa}$, $700 \mathrm{hPa}$ và $500 \mathrm{hPa}$ trong 134 ngày xảy ra mưa lớn trong mùa đông trên khu vực Tây Bắc, bài báo đi đến một số kết luận sau:

Về hình thế thời tiết ở các mục đẳng áp:

1. Có 05 hình thế chi phối ở mực $1000 \mathrm{hPa}$ trong các ngày xảy ra mưa lớn trên khu vực gồm KKL, KKLLĐ, tương tác giữa KKL hoặc KKLLĐ với rìa áp thấp phía tây, tương tác giữa KKL với gió đông hoặc gió đông-đông nam và KKLTC;

2. Ở mực $850 \mathrm{hPa}$, có 08 tổ hợp hình thế, trong đó có 05 hình thế trùng với mực $1000 \mathrm{hPa}$ và 03 hình thế gồm: Hội tụ giữa KKL và (hoặc) gió đông-đông nam với đới gió tây, tương tác giữa $\mathrm{KKL}$ với rìa $\mathrm{ACTBD}$ và tương tác giữa KKL hoặc KKLLĐ với gió tây nam từ rìa xoáy thuận dị thường trên vịnh Bengal;
3. Ở mực 700hPa, có 06 hình thế gồm: Hội tụ giữa rìa $\mathrm{ACTBD}$ với rãnh gió tây, rìa $\mathrm{ACTBD}$, rãnh gió tây, đới gió tây, hội tụ giữa rìa $\mathrm{ACTBD}$ với gió tây nam từ rìa xoáy thuận dị thường trên vịnh Bengal và $\mathrm{ACTBD}$. 5/6 hình thế trên, trừ hình thế thứ 5 cũng là 05 hình thế xuất hiện ở mực 500hPa;

4. Tần suất xuất hiện của các hình thế trên tất cả các mực đều có sự thay đổi từ đầu đông đến cuối đông nhưng sự thay đổi không có qui luật rõ ràng.

Về vai trò gây mưa lớn của hình thế ở các mucc:

6. Nhìn chung, hình thế ở các mực giữa có vai trò quyết định trong phần lớn các ngày xảy ra mưa lớn trong cả ba thời kỳ, trong đó, hình thế ở mực $700 \mathrm{hPa}$ có vai trò lớn hơn ở mực $500 \mathrm{hPa}$;

7. Hình thế ở các mực dưới tầng đối lưu vẫn có vai trò quyết định trong một số ít trường hợp, khi đó hình thế ở mực $850 \mathrm{hPa}$ thường có vai trò lớn hơn mực $1000 \mathrm{hPa}$.

Bảng 2. Tổ hợp hình thế trong nhũng ngày xảy ra mưa lớn trên khu vực Tây Bắc Bộ thời kỳ đầu đông ở tất cả các mục khí áp

\begin{tabular}{|c|c|c|c|c|c|c|c|}
\hline \multicolumn{4}{|c|}{ Tầng đối lưu dưới } & \multicolumn{4}{|c|}{ Tầng đối lưu giữa } \\
\hline \multicolumn{2}{|c|}{ Mực 1000hPa } & \multicolumn{2}{|l|}{ Mực 8500hPa } & \multicolumn{2}{|l|}{ Mực $700 \mathrm{hPa}$} & \multicolumn{2}{|l|}{ Mực $500 \mathrm{hPa}$} \\
\hline Hình thế & $\begin{array}{c}\text { Số } \\
\text { ngày }\end{array}$ & Hình thế & $\begin{array}{c}\text { Số } \\
\text { ngày }\end{array}$ & Hình thế & $\begin{array}{c}\text { Số } \\
\text { ngày }\end{array}$ & Hình thế & $\begin{array}{c}\text { Số } \\
\text { ngày }\end{array}$ \\
\hline \multirow[t]{17}{*}{ KKL } & 33 & KKL & 18 & Rìa ACTBD+Rãnh gió tây & 10 & $\begin{array}{l}\text { Rìa ACTBD+Rãnh gió tây } \\
\text { Rãnh gió tây }\end{array}$ & $\begin{array}{l}9 \\
1\end{array}$ \\
\hline & & & & Rãnh gió tây & 1 & Rãnh gió tây & 1 \\
\hline & & & & Rìa ACCNĐ & 6 & Rìa ACCNĐ & 3 \\
\hline & & & & & & ACCNĐ & 2 \\
\hline & & & & & & Đới gió tây & 1 \\
\hline & & & & $\begin{array}{c}\text { Rìa ACCNĐ+Gió tây nam từ rìa } \\
\text { XT trên vịnh bengal }\end{array}$ & 1 & Đới gió tây & 1 \\
\hline & & KKL+Gió tây & 5 & Rìa ACTBD+Rãnh gió tây & 4 & Rìa ACTBD+Rãnh gió tây & 1 \\
\hline & & & & & & Đới gió tây & 1 \\
\hline & & & & & & Rãnh gió tây & 2 \\
\hline & & & & Đới gió tây & 1 & Rìa ACTBD+Rãnh gió tây & 1 \\
\hline & & KKL+Gió đông & 8 & Rìa ACCNĐ & 7 & Rìa ACCNĐ & 4 \\
\hline & & & & & & Rãnh gió tây & 1 \\
\hline & & & & & & $\mathrm{ACCNĐ}$ & 1 \\
\hline & & & & & & Rìa ACTBD+Rãnh gió tây & 1 \\
\hline & & & & Rìa ACTBD+Rãnh gió tây & 1 & Rìa ACTBD+Rãnh gió tây & 1 \\
\hline & & $\mathrm{KKL}+$ Gió tây nam từ rìa $\mathrm{XT}$ & 2 & Rìa $\mathrm{ACCNĐ+} \mathrm{Gió} \mathrm{tây} \mathrm{nam} \mathrm{từ} \mathrm{rìa}$ & 2 & Rãnh gió tây & 1 \\
\hline & & trên vịnh bengal & & XT trên vịnh bengal & & Rìa ACTBD+Rãnh gió tây & 1 \\
\hline \multirow[t]{6}{*}{ KKLLĐ } & 7 & KKL & 3 & Rìa ACCNĐ & 2 & Rãnh gió tây & 1 \\
\hline & & & & & & Đới gió tây & 1 \\
\hline & & & & ACCNĐ & 1 & Rìa ACTBD+Rãnh gió tây & 1 \\
\hline & & KKL+Rìa ACCNĐ & 2 & Rìa ACCNĐ & 2 & Rìa ACCNĐ & 2 \\
\hline & & KKL+Áp thấp phía tây & 1 & $\mathrm{ACCN}$ & 1 & Rìa ACTBD+Rãnh gió tây & 1 \\
\hline & & $\begin{array}{c}\text { KKLLĐ+Gió tây nam từ rìa } \\
\text { XT trên vịnh bengal }\end{array}$ & 1 & $\begin{array}{c}\text { Rìa ACCNĐ+Gió tây nam từ rìa } \\
\text { XT trên vịnh bengal }\end{array}$ & 1 & Đới gió tây & 1 \\
\hline \multirow{2}{*}{$\begin{array}{l}\text { KKL+Áp thấp } \\
\text { phía tây }\end{array}$} & 2 & KKL+gió tây & 2 & Rìa ACTBD+Rãnh gió tây & 2 & Rãnh gió tây & 1 \\
\hline & & & & & & Đới gió tây & 1 \\
\hline \multirow{2}{*}{$\begin{array}{l}\text { KKL+Gió đông- } \\
\text { đông nam }\end{array}$} & 3 & KKL+Rìa ACCNĐ & 3 & Rìa ACCNĐ & 3 & Rìa ACCNĐ & 2 \\
\hline & & & & & & Rìa ACTBD+Rãnh gió tây & 1 \\
\hline
\end{tabular}




\section{BÀI BÁO KHOA HỌC}

Bảng 3. Tổ hơp hình thế trong nhũng ngày xảy ra mưa lớn trên khu vục Tây Bắc Bộ thời kỳ giũua đông ở tất cả các mực khíáp

\begin{tabular}{|c|c|c|c|c|c|c|c|}
\hline \multicolumn{4}{|c|}{ Tầng đối lưu dưới } & \multicolumn{4}{|c|}{ Tầng đối lưu giữa } \\
\hline \multicolumn{2}{|c|}{ Mực 1000hPa } & \multicolumn{2}{|l|}{ Mực $850 \mathrm{hPa}$} & \multicolumn{2}{|l|}{ Mực 700hPa } & \multicolumn{2}{|l|}{ Mực 500hPa } \\
\hline Hình thế & $\begin{array}{c}\text { Số } \\
\text { ngày }\end{array}$ & Hình thế & $\begin{array}{c}\text { Số } \\
\text { ngày }\end{array}$ & Hình thế & $\begin{array}{c}\text { Số } \\
\text { ngày }\end{array}$ & Hình thế & $\begin{array}{c}\text { Số } \\
\text { ngày }\end{array}$ \\
\hline \multirow[t]{15}{*}{ KKL } & 21 & KKL & 9 & Rìa ACTBD+Rãnh gió tây & 4 & Đới gió tây & 4 \\
\hline & & & & Rãnh gió tây & 2 & Rãnh gió tây & 1 \\
\hline & & & & & & Đới gió tây & 1 \\
\hline & & & & Rìa ACCNĐ & 2 & Rìa ACTBD+Rãnh gió tây & 1 \\
\hline & & & & & & Đới gió tây & 1 \\
\hline & & & & Đới gió tây & 1 & Đới gió tây & 1 \\
\hline & & KKLLĐ & 3 & Rìa ACCNĐ & 2 & Đới gió tây & 2 \\
\hline & & & & Rìa ACTBD+Rãnh gió tây & 1 & Đới gió tây & 1 \\
\hline & & KKL+ Áp thấp phía tây & 1 & Đới gió tây & 1 & Đới gió tây & 1 \\
\hline & & KKL, gió đông+Gió tây & 4 & Rìa ACTBD+Rãnh gió tây & 3 & Rãnh gió tây & 2 \\
\hline & & & & & & Đới gió tây & 1 \\
\hline & & & & Đới gió tây & 1 & Đới gió tây & 1 \\
\hline & & KKL + Rìa ACCNĐ & 3 & Rìa ACCNĐ & 3 & Rìa ACTBD+Rãnh gió tây & 2 \\
\hline & & & & & & Đới gió tây & 1 \\
\hline & & KKL+Rìa ACCNĐ+Gió tây & 1 & Rìa ACTBD+Rãnh gió tây & 1 & Đới gió tây & 1 \\
\hline \multirow[t]{7}{*}{ KKLLĐ } & 10 & KKL & 8 & Rãnh gió tây & 3 & Rãnh gió tây & 3 \\
\hline & & & & Rìa ACCNĐ & 2 & Rìa ACTBD+Rãnh gió tây & 1 \\
\hline & & & & & & Đới gió tây & 1 \\
\hline & & & & ACCNĐ & 2 & Rìa ACTBD+Rãnh gió tây & 1 \\
\hline & & & & & & Rãnh gió tây & 1 \\
\hline & & & & Rìa ACTBD+Rãnh gió tây & 1 & Rãnh gió tây & 1 \\
\hline & & KKLLĐ & 2 & Rãnh gió tây & 2 & Rãnh gió tây & 2 \\
\hline \multirow{4}{*}{$\begin{array}{l}\text { KKL+Áp } \\
\text { thấp phía tây }\end{array}$} & 4 & TT KKL + Đới gió đông & 2 & Rìa ACCNĐ & 1 & Rìa ACCNĐ & 1 \\
\hline & & & & Đới gió tây & 1 & Đới gió tây & 1 \\
\hline & & KKL+Gió tây & 2 & Đới gió tây & 1 & Đới gió tây & 1 \\
\hline & & & & Rãnh gió tây & 1 & Rìa ACTBD+Rãnh gió tây & 1 \\
\hline KKLTC & 1 & $\begin{array}{l}\text { KKL+ Đới gió đông, đông nam+Đới } \\
\text { gió tây }\end{array}$ & 1 & Rìa ACTBD+Rãnh gió tây & 1 & Rãnh gió tây & 1 \\
\hline
\end{tabular}

Bảng 4. Tổ hợp hình thế trong những ngày xảy ra mưa lớn trên khu vục Tây Bắc Bộ thời kỳ cuối đông ở tất cả các mưc khí áp

\begin{tabular}{|c|c|c|c|c|c|c|c|}
\hline \multicolumn{4}{|c|}{ Tầng đối lưu dưới } & \multicolumn{4}{|c|}{ Tầng đối lưu giữa } \\
\hline \multicolumn{2}{|l|}{ Mực $1000 \mathrm{hPa}$} & \multicolumn{2}{|l|}{ Mực $850 \mathrm{hPa}$} & \multicolumn{2}{|l|}{ Mực $700 \mathrm{hPa}$} & \multicolumn{2}{|l|}{ Mực $500 \mathrm{hPa}$} \\
\hline Hình thế & $\begin{array}{c}\text { Số } \\
\text { ngày }\end{array}$ & Hình thế & Số ngày & Hình thế & $\begin{array}{c}\text { Số } \\
\text { ngày }\end{array}$ & Hình thế & $\begin{array}{c}\text { Số } \\
\text { ngày }\end{array}$ \\
\hline \multirow[t]{13}{*}{ KKL } & 28 & KKL & 20 & Rìa ACTBD+Rãnh gió tây & 10 & Rìa ACTBD+Rãnh gió tây & 4 \\
\hline & & & & & & Rãnh gió tây & 5 \\
\hline & & & & & & Đới gió tây & 1 \\
\hline & & & & Rãnh gió tây & 2 & Đới gió tây & 2 \\
\hline & & & & Rìa ACCNĐ & 5 & Rìa ACTBD+Rãnh gió tây & 4 \\
\hline & & & & & & Đới gió tây & 1 \\
\hline & & & & Đới gió tây & 3 & Đới gió tây & 2 \\
\hline & & & & & & Rìa ACTBD+Rãnh gió tây & 1 \\
\hline & & KKLLĐ & 1 & $\begin{array}{l}\text { HTKH giữa rìa ACCNĐ và } \\
\text { rãnh gió tây }\end{array}$ & 1 & Đới gió tây & 1 \\
\hline & & KKL, gió đông+Gió tây & 7 & Rìa ACTBD+Rãnh gió tây & 5 & Rìa ACTBD+Rãnh gió tây & 4 \\
\hline & & & & & & Đới gió tây & 1 \\
\hline & & & & Rãnh gió tây & 1 & Đới gió tây & 1 \\
\hline & & & & Đới gió tây & 1 & Đới gió tây & 1 \\
\hline \multirow[t]{5}{*}{ KKLLĐ } & 7 & KKL & 4 & Rãnh gió tây & 3 & Rãnh gió tây & 3 \\
\hline & & & & Rìa ACCNĐ & 1 & Rãnh gió tây & 1 \\
\hline & & KKLLĐ & 1 & Rìa ACTBD+Rãnh gió tây & 1 & Rìa ACTBD+Rãnh gió tây & 1 \\
\hline & & TT KKL + Đới gió đông & 1 & Rìa ACTBD+Rãnh gió tây & 1 & Rãnh gió tây & 1 \\
\hline & & $\begin{array}{l}\text { KKL+ Đới gió đông, } \\
\text { đông nam+Đới gió tây }\end{array}$ & 1 & Rãnh gió tây & 1 & Rãnh gió tây & 1 \\
\hline \multirow{10}{*}{$\begin{array}{l}\text { KKL+ Áp thấp phía } \\
\text { tây }\end{array}$} & 16 & KKL & 2 & Rìa ACTBD+Rãnh gió tây & 1 & Rãnh gió tây & 1 \\
\hline & & & & Đới gió tây & 1 & Rãnh gió tây & 1 \\
\hline & & KKLLĐ & 2 & Rìa ACTBD+Rãnh gió tây & 2 & Rãnh gió tây & 1 \\
\hline & & & & & & Rìa ACTBD+Rãnh gió tây & 1 \\
\hline & & KKL+gió tây & 4 & Rìa ACTBD+Rãnh gió tây & 2 & Rìa ACTBD+Rãnh gió tây & 1 \\
\hline & & & & & & Rãnh gió tây & 1 \\
\hline & & & & Đới gió tây & 1 & Đới gió tây & 1 \\
\hline & & & & Rãnh gió tây & 1 & Đới gió tây & 1 \\
\hline & & KKL + Rìa ACCNĐ & 2 & Rãnh gió tây & 1 & Đới gió tây & 1 \\
\hline & & & & Rìa ACTBD+Rãnh gió tây & 1 & Đới gió tây & 1 \\
\hline
\end{tabular}


BÀI BÁO KHOA HỌC

\begin{tabular}{|c|c|c|c|c|c|c|c|}
\hline \multicolumn{4}{|c|}{ Tầng đối lưu dưới } & \multicolumn{4}{|c|}{ Tầng đối lưu giữa } \\
\hline Mực 1000hP & & Mực 850hPa & & Mực $700 \mathrm{hPa}$ & & Mực $500 \mathrm{hPa}$ & \\
\hline \multirow[t]{7}{*}{ Hình thế } & $\begin{array}{c}\text { Số } \\
\text { ngày }\end{array}$ & Hình thế & Số ngày & Hình thế & $\begin{array}{c}\text { Số } \\
\text { ngày }\end{array}$ & Hình thế & $\begin{array}{c}\text { Số } \\
\text { ngày }\end{array}$ \\
\hline & & KKL/KKLLĐ+ Áp thấp & 3 & Rìa ACTBD+Rãnh gió tây & 1 & Rìa ACTBD+Rãnh gió tây & 1 \\
\hline & & phía tây & & Rìa ACCNĐ & 1 & Rìa ACTBD+Rãnh gió tây & 1 \\
\hline & & & & Đới gió tây & 1 & Đới gió tây & 1 \\
\hline & & Rìa CCNĐ+Gió tây & 2 & Rìa ACTBD+Rãnh gió tây & 2 & Rìa ACTBD+Rãnh gió tây & 1 \\
\hline & & & & & & Rãnh gió tây & 1 \\
\hline & & $\begin{array}{c}\text { KKL+Rìa CCNĐ+Gió } \\
\text { tây }\end{array}$ & 1 & Rìa ACTBD+Rãnh gió tây & 1 & Đới gió tây & 1 \\
\hline $\begin{array}{l}\text { HT KKL+Đới gió } \\
\text { đông-đông nam }\end{array}$ & 1 & $\begin{array}{l}\text { KKL+Rìa ACCNĐ+Rìa } \\
\text { áp thấp phía tây }\end{array}$ & 1 & Rãnh gió tây & 1 & Đới gió tây & 1 \\
\hline KKLTC & 1 & KKLTC & 1 & Rìa ACTBD+Rãnh gió tây & 1 & Rìa ACTBD+Rãnh gió tây & 1 \\
\hline
\end{tabular}

\section{Tài liệu tham khảo}

1. Trần Việt Liễn (2010), Giáo trình Khí hậu Việt Nam. Truờng Đại học Tài nguyên và Môi trường.

2. Nguyễn Xiển, Phạm Ngọc Toàn, Phan Tất Dắc (1968), Đặc điểm khi hậu miền Bắc. NXB Khoa học kỹ thuật Hà Nội.

3. Phạm Vũ Anh, Nguyễn Viết Lành (2009), Nghiên cứu ảnh hưởng của không khí lạnh luc địa tới miền Bắc Việt Nam trong mùa thu bằng chuỗi số liệu tái phân tích. Tạp chí Khí tượng thủy văn, $577,1-5$.

4. Thái Thị Thanh Minh, Trần Thị Huyền Trang (2015), Rãnh Đông Á và sụ biến đổi của nó qua nhũng thập kỷ gần đây. Tạp chí Khí Tượng Thủy Văn, 655, 23-30.

5. Yang, S., William, K.M. Lau, Kim, K.M., (2002), Variations of the East Asian Jet Stream and Asian-Pacific-American Winter Climate Anomalies. Journal of Climate, 15 (3), 306-325.

6. Arvin, A., Sajadian, S.M., Ghangherme, A., Heydari, J., (2015), The Role of Subtropical JetStream in Daily Precipitation More Than 10mm in Zayanderood Basin. Physical Geography Research Quarterly, 47 (1), 18-20.

7. Nguyễn Đức Ngữ (2002), Tác động của ENSO đến thời tiết, khi hậu, môi trường và kinh tếxã họi ở Việt Nam. Báo cáo tổng kết đề tài NCKH cấp quốc gia.

8. Zhou, L.T., Tam, C.Y., Zhou, W., Chan, J.C.L., (2010), Influence of South China Sea SST and the ENSO on winter rainfall over South China. Advances in Atmospheric Sciences, 27 (4), 832844.

9. Zhang, Z., Gong, D.Y., Hu, M., Guo, D., He, X., Lei, Y., (2009), Anomalous winter temperature and precipitation events in southern China, Journal of Geographical Sciences 19(4): 471-488.

10. Wu, R., Hu, Z.Z., Kirtman, B.P., (2003), Evolution of ENSO-Related Rainfall Anomalies in East Asia. Journal of Climate, 16, 3742-3758.

11. Hiroshi, G., Takahashi, Idenaga, T., (2013), Impact of SST on Precipitation and Snowfall on the Sea of Japan Side in the Winter Monsoon Season: Timescale Dependency. Journal of the Meteorological Society of Japan, 91 (5), 639-653. 


\title{
BÀI BÁO KHOA HỌC
}

\section{WEATHER FORMS IN THE WINTER HEAVY RAINFALL DAYS ON THE WEST-NORTHERN REGION OF VIETNAM \\ Tran Dinh Linh', Pham Minh Tien ${ }^{1}$, Chu Thi Thu Huong ${ }^{1}$ \\ ${ }^{1}$ Faculty of Meteorology and Hydrology, \\ Hanoi University of Natural Resources and Environment}

\begin{abstract}
Study uses the ERA Interim reanalysis data to construct the current field maps on four standard isometric pressure levels of $1000 \mathrm{hPa}, 850 \mathrm{hPa}, 700 \mathrm{hPa}$ and $500 \mathrm{hPa}$ for 134 heavy rainfall days to identify the weather forms which cause the winter heavy rainfall in the West-Northern region. The results show, at the lower levels of the troposphere (1000hPa, 850hPa), weather forms are mainly unfavorable to cause heavy rain. Most of the time, cold air dominates the region at these levels. In contrast, the formsn at the middle levels $(700 \mathrm{hPa}, 500 \mathrm{hPa})$ is very beneficial to cause rain. On most days of heavy rain, on areas affected by the West Pacific high edge, the west wind trough or the convergence between them. Regarding the role of rainfall, the forms at the middle levels play decisive role in most of time, in which, the forms at the 700hPa level play more impotant role than the 500hPa. However, in several cases when the situation at the middle levels is not favorable, the situation at the lower levels is crucial.
\end{abstract}

Keywords: Weather shapes, Winter heavy rainfall, The West-Northern region of Vietnam. 